\title{
Hubungan Penerimaan Diri pada Orangtua terhadap Kreativitas Individu dengan ASD Dengan Moderator Dukungan Sosial Pada Orangtua
}

\author{
Adika El Nino ${ }^{1}$ Edilburga Wulan Saptandari ${ }^{2}$
}

1,2Fakultas Psikologi UGM

Jl. Sosio Humaniora Bulaksumur, Karang Malang, Caturtunggal, Kec. Depok, Kabupaten Sleman, Daerah Istimewa Yogyakarta 55281

\begin{abstract}
Everyone is born with different conditions. On such condition is that individuals are born with ASD conditions. Even with the different conditions, but indivudals still have the potential that can be developed. One of these potentials is related to creativity. With the self-acceptance and perceived social support by parents, parents are expected to be able to practice parenting that is suitable for individuals with ASD to develop their potential. The study involved 34 students with autistic and parents in three districts and one municipality in the Daerah Istimewa Yogyakarta. There instruments used were the Torrance Tests of Creative Thinking-Figural, Multidimensional Scale of Perceived Social Support, and Scale of Self-acceptance. Findings from this study indicate that selfacceptance in parents can not predict of individuals with ASD. Then, the social support felt by parents can predict the creativity of individuals with ASD. In addition, social support for parents does not act as a moderator in the relationship between self-acceptance in parents and creativity of individuals with ASD. This is not in line with previous findings.
\end{abstract}

Keywords: parents self acceptance; perceived social support; creativity; autism spectrum disorder

Abstrak. Setiap individu dilahirkan dengan kondisi yang berbeda. Salah satu kondisi tersebut ialah individu dilahirkan dengan kondisi ASD. Meski dengan perbedaan kondisi, tetapi individu tersebut tetap memiliki potensi yang dapat dikembangkan, salah satu potensi tersebut berkaitan dengan kreativitas. Dengan adanya penerimaan diri dan dukungan sosial pada orangtua, diharapkan orangtua dapat menjalankan pola asuh yang sesuai untuk individu dengan ASD guna mengembangkan potensinya. Penelitian melibatkan 34 siswa dengan autis dan wali siswa di tiga kabupaten dan satu kotamadya di Daerah Istimewa Yogyakarta. Alat ukur yang digunakan, yaitu Torrance Tests of Creative Thinking-Figural, Multidimensional Scale of Perceived Social Support, dan skala penerimaan diri. Temuan dari penelitian ini menunjukkan bahwa penerimaan diri pada orangtua tidak dapat memprediksi kreativitas individu dengan ASD. Kemudian, dukungan sosial yang dirasakan oleh orangtua dapat memprediksi kreativitas individu dengan ASD. Selain itu, dukungan sosial pada orangtua tidak berperan sebagai moderator 
pada hubungan penerimaan diri pada orangtua dan kreativitas individu dengan ASD.

Kata kunci: autis, dukungan sosial, kreativitas, penerimaan diri orangtua.

\section{Pendahuluan}

Penduduk dengan Autism Spectrum Disorder (ASD) di Indonesia diperkirakan sebanyak 2,4 juta (0.01\%) orang pada tahun 2010. Hal tersebut dikemukakan oleh Kementerian Pemberdayaan Perempuan dan Perlindungan Anak yang merujuk pada Incidence and Prevalence ASD bahwa terdapat sepuluh kasus per seribu penduduk ${ }^{1}$. Sementara itu, menurut World Health Organization setiap 160 anak terdapat satu anak yang mengalami ASD2. Setiap tahunnya prevalensi individu mengalami gangguan ASD secara global mengalami peningkatan (Onaolapo \& Onaolapo, 2017).

ASD merupakan gangguan yang dicirikan dengan berbagai tingkat gangguan dalam kemampuan berkomunikasi, interaksi sosial, dan pola perilaku yang terbatas, berulang, dan stereotip (Service, 2007). Menurut Diagnostic and Statistical Manual (DSM) V, ASD dicirikan dengan kekurangan dalam kemampuan komunikasi verbal dan non-verbal dalam interaksi sosial. Selain itu, individu dengan ASD mempunyai perilaku, ketertarikan, maupun aktivitas yang berulang dan terbatas. Karakteristik perilaku yang dimiliki oleh individu dengan ASD seperti aktivitas yang berulang, agresif, dan disruptif dapat disebut dengan perilaku mal adaptif (Fulton, dkk., 2014). Individu dengan ASD juga mengalami ketidakberfungsian pada bagian eksekutif di otak yang menyebabkan individu dengan ASD menunjukkan perilaku yang kurang imajinatif (Davis, Simon, Meins, \& Robins, 2018). Individu dengan ASD juga memerlukan perawatan medis jangka panjang yang lebih khusus (Al-Dujaili \& Al-Mosssawy, 2017). Perawatan medis tersebut dapat berupa terapi bicara, terapi fisik, pengobatan psikotropika, dan terapi modifikasi perilaku atau keterampilan sosial (Wang, Mandell, Lawer, Cidav, \& Leslie, 2013).

Keterbatasan yang dialami oleh individu dengan ASD menyebabkan ia membutuhkan bantuan dari orang lain sebagai caregiver untuk melakukan aktivitas dalam kehidupan sehari-hari (Cloete \& Obaigwa, 2019). Lebih jelasnya, caregiver merupakan seseorang yang memberi perawatan kepada orang-orang yang membutuhkan bantuan untuk merawat dirinya sendiri. Caregiver ini dapat berupa tenaga profesional, anggota keluarga, teman, maupun pekerja sosial. Caregiver utama bagi individu dengan ASD ialah orangtuanya sendiri.

\footnotetext{
${ }^{1}$ Kementerian Pemberdayaan Perempuuan dan Perlindungan Anak Republik Indonesia, Hari Peduli ASD Sedunia: Kenali Gejalanya, Pahami Keadaannya, https://www.kemenpppa.go.id/index.php/page/read/31/1682/hari-peduli-ASD-sedunia-kenali-gejalanya-pahamikeadaannya, diunduh pada 12 April 2019 pukul 18.09.

${ }^{2}$ World Health Organization, Autism Spectrum Disorder, diunduh dari https://www.who.int/news-room/factsheets/detail/autism-spectrum-disorders, pada 12 Desember 2019 pukul 16.30.
} 
ASD merupakan kondisi yang dialami seumur hidup. Sehingga pendampingan untuk individu dengan ASD membutuhkan waktu dan usaha yang lebih daripada individu tanpa ASD (Hoefman, dkk., 2014). Caregiver khususnya orangtua dapat mengalami stres yang disebabkan oleh beberapa faktor. Faktor-faktor tersebut yaitu dukungan sosial yang kurang, persepsi negatif dan pemahaman orangtua yang kurang mengenai ASD, dan kecemasan orangtua mengenai masa depan anak (Ilias, Cornish, Kummar, Sang-Ah Park, \& Golden, 2018). Selain itu, kesulitan lain dalam merawat individu dengan ASD ialah mengenai masalah finansial karena individu dengan ASD memerlukan perawatan medis jangka panjang (Hoefman, dkk., 2014). Perawatan medis tersebut seperti terapi fisik, terapi perilaku, terapi bicara, dan pengobatan psikotropika yang diberikan tidak hanya sekali (Wang, Mandell, Lawer, Cidav, \& Leslie, 2013). Caregiver individu dengan ASD juga dapat mengalami beban psikososial yang berpengaruh pada kesehatan mentalnya (Al-Dujaili \& Al-Mosssawy, 2017). Tidak jarang orangtua dari individu dengan ASD mengalami tingkat kesejahteraan psikologis yang rendah, gejala depresi, dan kecemasan (Hoefman, dkk., 2014; Ozgur, Aksu, \& Eser, 2018).

Orangtua dari individu dengan ASD sering kali mendapatkan kesulitan yang lebih tinggi dalam mengasuh anaknya. Semakin parah perilaku mal adaptif yang ditunjukkan individu dengan ASD semakin meningkat kesulitan dalam mengasuh individu tersebut (Tung, dkk., 2014). Selain itu, orangtua dari individu dengan ASD seringkali mengalami stres psikologis yang lebih tinggi, tetapi mendapatkan dukungan sosial yang lebih rendah daripada orangtua dari individu tanpa ASD (Picardi, dkk., 2018). Hal ini dikarenakan keluarga maupun teman tidak memahami mengenai ASD, bahkan meskipun jika menerima diagnosis mereka tidak dapat memberikan dukungan yang dibutuhkan (Picardi, dkk., 2018). Stigma pada masyarakat, pengucilan, dan penolakan juga meningkatkan kesulitan dalam mengasuh individu dengan ASD (Kinnear, Link, Ballan, \& Fischbach, 2016). Stigma negatif mengenai individu dengan ASD tersebut seringkali muncul karena kesalahpahaman masyarakat mengenai gangguan ASD (Mak \& Kwok, 2010). Ketika orangtua mengalami perlakuan buruk terkait stigma yang menempel pada individu dengan ASD, maka stigma tersebut akan mudah diinternalisasi oleh orangtua (Mak \& Kwok, 2010).

Berdasarkan kondisi individu dengan ASD dan perawatannya yang telah dipaparkan sebelumnya, orangtua sebagai caregiver harus memiliki kemampuan yang dibutuhkan dalam merawat individu dengan ASD. Salah satu kemampuan yang diperlukan ialah penerimaan diri sebagai orangtua dan kesediaannya menjalankan peran sebagai orangtua tersebut. Menurut Sheerer (1949), terdapat beberapa ciri yang menunjukkan bahwa individu mampu menerima diri. Ciri tersebut diantaranya individu berperilaku sesuai dengan norma yang ditentukan oleh diri sendiri dan merasa mempunyai derajat yang sama dengan orang lain. Orang yang tidak 
mampu menerima diri sendiri dapat menyebabkan berbagai kesulitan emosional, seperti kemarahan dan depresi yang tidak terkendali (Carson \& Langer, 2006).

Ketika mengetahui anaknya memiliki ASD, orangtua akan merasa terkejut, yang kemudian akan mengarah pada munculnya perasaan bersalah dan marah sampai tiba pada tahap negosiasi yang akan menghasilkan penerimaan atas keadaan anaknya (Ibrahimi, Durmishi, \& Ibrahimi, 2019). Orangtua yang belum menerima kondisi anak dapat merasa frustrasi (Mansell \& Morris, 2004), padahal penolakan yang terlalu lama pada keadaan anak akan memengaruhi hubungan orangtua dan anak itu sendiri (Ibrahimi, Durmishi, \& Ibrahimi, 2019). Selain itu, orangtua dengan penerimaan diri yang rendah cenderung selalu melakukan evaluasi diri yang berlebihan. Ketika melakukan evaluasi diri yang berlebihan tersebut, orangtua akan mencurahkan tenaga dan kemampuan yang dimilikinya untuk menutupi kekurangannya supaya terlihat lebih baik (Carson \& Langer, 2006).

Sementara itu, tenaga dan kemampuan yang dimiliki tersebut dapat dicurahkan pada individu dengan ASD yang membutuhkan perhatian lebih daripada individu lainnya. Jika orangtua memiliki penerimaan diri yang tinggi, maka orangtua dapat melakukan pola asuh yang sesuai untuk individu dengan ASD (Oana, DiGiuseppe, \& David, 2013). Pola asuh yang sesuai untuk individu dengan ASD ialah pola asuh otoritatif (Green, Furrer, \& McAllister, 2007). Menurut Baumrind (1991) pola asuh otoritatif ini ditandai dengan orangtua menetapkan standar untuk anak, memantau perilaku mereka, bersikap tegas, tetapi tidak mengganggu maupun membatasi, serta mendorong anak untuk bersikap tegas dan kooperatif. Selain itu, penerimaan diri pada orangtua dari individu dengan ASD dapat menurunkan masalah kesehatan mental, seperti stres, yang dialami oleh orangtua dari individu dengan ASD (Weiss, Cappadocia, MacMullin, Viecili, \& Lunsky, 2012). Berdasarkan penelitian-penelitian itu, penerimaan diri dibutuhkan oleh orangtua dari individu dengan ASD.

Perawatan individu dengan ASD juga membutuhkan dukungan dari pihak eksternal berupa dukungan sosial. Hal ini karena caregiver individu dengan ASD merasakan stres yang signifikan saat merawat individu dengan ASD tersebut (Adip, dkk., 2019). Dukungan sosial mengacu pada ketersediaan dan kecukupan koneksi sosial (Eagle, Hybels, \& Proeschold-Bell, 2018). Hubungan antara dukungan sosial yang dirasakan dengan stres telah dibuktikan dengan penelitian yang menyatakan bahwa dukungan sosial yang dirasakan khususnya dari teman menjadi faktor penting dalam perlindungan terhadap stres (Colbert, Drogomyretska, \& Fox, 2020). Dukungan sosial pun juga terbukti baik memediasi memoderasi pengaruh stres pada orangtua dari individu dengan ASD terhadap kepuasan hidup (Lu, dkk., 2018). 
Dukungan sosial juga dapat memengaruhi kesehatan mental. Penelitian yang dilakukan oleh Yuananti (2017) menunjukkan bahwa dukungan sosial mempunyai pengaruh yang signifikan dalam mengurangi gejala depresi dan kecemasan pada caregiver orang dengan skizofernia. Hal ini dikarenakan dukungan sosial yang memadai dapat melindungi orang dari berbagai patologis, seperti ketergantungan alkohol, depresi, dan berbagai macam gangguan jiwa lainnya (Cobb, 1976). Ozbay, dkk. (2007) menjelaskan bahwa dukungan sosial dapat memberikan ketahanan terhadap stres, melalui efeknya pada sistem hipotalamus-hipofisis-adrenokortikal (HPA), sistem noradrenergik, dan jalur oksitosin sentral. Penelitian tersebut juga didukung oleh penelitian dari Eagle, Hybels, \& Proeschold-Bell (2018) yang menunjukkan bahwa dukungan sosial yang dirasakan oleh individu memiliki hubungan yang signifikan dengan rendahnya gejala depresi, sedangkan dukungan sosial yang diterima yang hanya memiliki hubungan yang kecil dengan rendahnya gejala depresi. Dukungan sosial juga dapat mengurangi stres psikologis, meningkatkan imunitas tubuh, sebagai prediktor kesejahteraan, dan menjadi faktor protektif dari depresi maupun kecemasan (Walen \& Lachman, 2000; Reblin \& Uchino, 2008; Orpana \& O’Shea, 2012; Roohafza, dkk., 2014).

Dukungan sosial dan penerimaan diri diperlukan dalam pengasuhan individu dengan ASD. Penelitian dari Green, Furrer, \& McAllister (2007) menunjukkan hasil bahwa orangtua dengan lebih banyak dukungan sosial menunjukkan peningkatan kegiatan orangtua dan anak dari waktu ke waktu. Efek ini dimediasi oleh keterikatan ibu khususnya keterikatan yang cenderung ambivalen (Green, Furrer, \& McAllister, 2007). Selain itu, dukungan sosial yang dirasakan oleh ibu berkontribusi terhadap kompetensi sosial anak karena hubungan positif antara dukungan sosial dengan pemantauan ibu (Taylor, Conger, Robins, \& Widaman, 2015)

Tidak jarang orangtua dari individu dengan ASD merasa malu (Ramanda, 2008). Oleh karena itu, dukungan sosial diperlukan untuk mencapai penerimaan diri. Penelitian membuktikan bahwa dukungan sosial yang diterima oleh orangtua dari individu dengan ASD dapat meningkatkan penerimaan diri dari orangtua tersebut (Lestari, 2017). Hal ini juga didukung oleh hasil penelitian yang melibatkan partisipan anak autis yang dilakukan oleh Kumalasari (2019) bahwa terdapat hubungan yang positif antara dukungan sosial dengan penerimaan diri pada orangtua dengan anak autis. Dengan penerimaan diri tersebut, orangtua dapat menerapkan pola pengasuhan yang sesuai bagi individu dengan ASD, yaitu pola asuh otoritatif (Oana, DiGiuseppe, \& David, 2013). Ketika orangtua menerapkan pola asuh otoritatif, maka hal tersebut akan berdampak pada kreativitas (Astuti, 2017). Hal ini dikarenakan dalam pola asuh otoritatif, anak diberikan kebebasan dalam mengembangkan kreativitasnya, namun tetap disertai bimbingan dari orangtua (Novianggraini, 2012). Orangtua dengan pola asuh otoritatif ini tegas dan pada saat bersamaan rasional, maka ketika orangtua membiarkan anak, mereka 
memutuskan untuk menyediakan lingkungan kegiatan kreatif yang mendasarinya (Assadi, Zokayi, Kaviani, Mohammadi, \& Gohari, 2006).

Kreativitas dalam ranah psikologi yakni merujuk pada kepribadian kreatif (Guilford, 1950). Kepribadian kreatif merupakan kepribadian yang dikarakteristikkan dengan munculnya kecenderungan individu untuk berperilaku kreatif. Perilaku kreatif tersebut meliputi aktivitas seperti menciptakan, merancang, membuat, menyusun, dan merencanakan (Guilford, 1950). Terdapat empat aspek yang diperlukan untuk menghasilkan perilaku kreatif menurut Torrance dalam Honeck (2016). Aspek yang pertama adalah kelancaran, yaitu kemampuan menghasilkan untuk ide selama proses kreatif. Aspek kedua adalah keaslian atau originality. Keaslian yang dimaksud adalah keunikan dari ide yang dihasilkan dibandingkan dengan ide-ide yang lainnya. Aspek ketiga dalam kreativitas ialah keluwesan, yaitu kemampuan untuk berpindah gagasan dari gagasan satu ke yang lainnya. Aspek yang terakhir ialah elaborasi, yaitu kemampuan untuk mengembangkan suatu gagasan sehingga menjadi gagasan yang lebih baik.

Literatur penelitian mengenai kreativitas individu dengan ASD seringkali mendukung klaim bahwa kreativitas sangat sulit atau tidak mungkin bagi individu dengan ASD (Craig \& Cohen, 1999). Berbeda dengan hasil penelitian yang membahas mengenai kreativitas verbal bahwa di antara orang dewasa serta anak-anak dengan ASD yang memiliki fungsi kognitif dan inteligensi yang tinggi, pemrosesan metafora baru sama atau bahkan lebih tinggi daripada individu tanpa ASD, baik dalam kreativitas maupun orisinalitas (Kasirer \& Mashal, 2014). Penelitian Kasirer dan Mashal (2014) mengenai kreativitas dan orisinalitas di antara individu dengan ASD, gambar dinilai berdasarkan orisinalitas mereka, fleksibilitas, elaborasi, dan keterbukaan juga menunjukkan bahwa individu dengan ASD mengungguli individu tanpa ASD. Berdasarkan hasil penelitian di atas, individu dengan ASD tetap memiliki kreativitas karena individu dengan ASD memiliki karakteristik perhatian dan ingatan yang berfokus pada hal detail yang memengaruhi perkembangan bakat (Happe \& Vital, 2009). Selain itu, temuan pada anatomi otak menunjukkan bahwa kekhasan minicolumnar terlihat pada individu dengan ASD dan juga ditemukan pada neurotipe ilmuwan yang berbakat (Casanova \& Trippe, 2009). Minicolumnar merupakan unit sel dan sering dianggap sebagai unit sel yang sangat berulang bahkan seperti klon, tetapi mereka menunjukkan heterogenitas yang cukup besar antara daerah dan spesies (Opris \& Casanova, 2014). Minicolumnar digunakan untuk memproses informasi di otak (Casanova, Switala, Trippe, \& Fitzgerald, 2007).

Beberapa individu dengan ASD berhasil menempuh pendidikan hingga mendapatkan kualifikasi pasca-sekolah menengah, bahkan hingga berpartisipasi dalam pekerjaan jangka panjang (Eaves \& Ho, 2007). Tidak menutup kemungkinan individu dengan ASD dapat bekerja juga. Oleh karena itu, kreativitas dibutuhkan oleh individu dengan ASD dalam bekerja. Terlebih pada era sekarang 
kreativitas sangat dibutuhkan sebagai salah satu kemampuan yang harus dimiliki. Menurut The World Economic Forum's (WEF) dalam Wilson, Lennox, Hughes, \& Brown (2017) kreativitas menduduki peringkat tiga dalam perkiraan sepuluh keterampilan yang dibutuhkan dalam pekerjaan pada tahun 2020.

Selain itu, melalui praktik kolaborasi kreativitas dapat mengembangkan keterampilan sosial dan emosional yang lebih baik (Lucas, dkk., 2013). Terlebih sekarang sebagian besar tempat kerja yang mempekerjakan individu dengan ASD memberikan pelatihan bagi individu dengan ASD untuk mengatasi kesulitan sosial dan komunikasi mereka (Hillier, dkk., 2007). individu dengan ASD juga memiliki pola pemikiran yang berbeda dengan individu tanpa ASD (Best, Arora, Porter, \& Doherty, 2015). Pola pemikiran seperti menghasilkan respon baru yang tidak biasa (Best, dkk., 2015), perhatian pada detail dan kurangnya ketertarikan akan perubahan (Astorga, 2014). Pola pemikiran yang berbeda tersebut dapat menghasilkan perilaku pemecahan masalah unik, maka jika dikembangkan dengan baik dapat menjadi kelebihan dari individu dengan ASD (Best, dkk., 2015).

Sampai saat ini belum ada penelitian yang membahas dukungan sosial yang dirasakan oleh orangtua dan penerimaan diri pada orangtua yang dikaitkan dengan kreativitas individu dengan ASD. Oleh sebab itu, penelitian ini bertujuan untuk menguji apakah dukungan sosial yang dirasakan oleh orangtua dapat memprediksi kreativitas individu dengan ASD, apakah penerimaan diri pada orangtua dapat memprediksi kreativitas individu dengan ASD, serta apakah dukungan sosial yang dirasakan oleh orangtua berperan sebagai moderator dalam hubungan antara penerimaan diri pada orangtua terhadap kreativitas individu dengan ASD. Hipotesis dalam penelitian ini, yakni

Penerimaan diri pada orangtua dapat memprediksi kreativitas individu dengan ASD.

Dukungan sosial yang dirasakan oleh orangtua dapat memprediksi kreativitas individu dengan ASD.

Terdapat peran dukungan sosial yang dirasakan oleh orangtua sebagai moderator dalam hubungan antara penerimaan diri pada orangtua terhadap kreativitas individu dengan ASD.

\section{Metode}

Penelitian ini merupakan penelitian kuantitatif dengan metode pengambilan data berupa survei. Penelitian kuantitatif itu sendiri merupakan proses untuk mendapatkan generalisasi hasil penelitian (Alsa, 2007). Pengolahan data dilakukan dengan metode analisis variabel moderasi. Tujuan dari penelitian ini untuk mengetahui apakah baik penerimaan diri pada orangtua maupun dukungan sosial yang dirasakan oleh orangtua dapat memprediksi kreativitas 
individu dengan ASD. Selain itu, untuk menguji apakah terdapat peran dukungan sosial yang dirasakan oleh orangtua sebagai moderator dalam hubungan penerimaan diri pada orangtua terhadap kreativitas individu dengan ASD.

\section{Partisipan penelitian}

Kriteria subjek penelitian ini adalah ayah atau ibu dari individu dengan ASD dan individu dengan ASD yang berusia 6-12 tahun atau yang masih bersekolah dasar. Penelitian melibatkan 34 siswa dan orangtua di beberapa SLB dan yayasan autis di Kabupaten Bantul, Sleman, Kulon Progo, dan Kota Yogyakarta. Data domisili partisippan dapat dilihat pada tabel 1. Kemudian data usia partisipan dapat dilihat pada tabel 2. Selanjutnya data kelamin partisipan dapat dilihat pada tabel 3. Pada penelitian ini tidak diketahui mengenai tingkat keparahan ASD partisipan. Hal ini disebabkan orangtua individu dengan ASD maupun instansi terkait tidak mengetahui tingkat keparahan individu dengan ASD tersebut.

\section{Tabel 1}

Data Domisili Partisipan

\begin{tabular}{ll}
\hline Kabupaten/kota & Jumlah \\
\hline Sleman & 14 \\
Bantul & 6 \\
Kota Yogyakarta & 9 \\
Kulon Progo & 3 \\
Luar DIY & 2 \\
\hline
\end{tabular}

Tabel 2.

Data Usia Partisipan

\begin{tabular}{ll}
\hline Rentang Usia & Jumlah \\
\hline $6-10$ & 17 \\
$11-15$ & 13 \\
$16-20$ & 4 \\
\hline
\end{tabular}


Data Jenis Kelamin Partisipan

\begin{tabular}{cc}
\hline Jenis Kelamin & Jumlah \\
\hline Laki-laki & 20 \\
Perempuan & 14 \\
\hline
\end{tabular}

\section{Prosedur}

Peneliti melakukan penelitian di Sekolah Luar Biasa C dan sekolah inklusi yang telah memberi izin untuk peneliti melakukan penelitian. Sebelumnya, peneliti mengurus perizinan pada tingkat fakultas yang selanjutnya akan diajukan kepada Dinas Pendidikan, Pemuda, dan Olahraga Daerah Istimewa Yogyakarta serta untuk sekolah yang dituju. Setelah mendapatkan surat izin untuk melakukan penelitian, peneliti menuju sekolah yang dituju untuk menyampaikan maksud, tujuan, serta surat izin untuk melakukan penelitian. Kemudian setelah mendapatkan izin dari pihak sekolah, peneliti melakukan pengambilan data. Sebelum pengambilan data, peneliti memperkenalkan diri serta tujuan kepada partisipan. Selanjutnya peneliti menyebarkan angket survei yang termasuk di dalamnya informed consent kepada orangtua dari individu dengan ASD yang telah bersedia mengikuti penelitian ini. Dalam informed consent tersebut juga dijelaskan secara singkat mengenai penelitian yang dilakukan, data diri orangtua dan anak, pernyataan persetujuan terlibat dalam penelitian, serta data diri peneliti. Pada penelitian ini tidak disertakan child assent karena partisipan individu dengan ASD dianggap tidak mampu untuk memberikan persetujuan. Selanjutnya orangtua mengisi biodata, skala dukungan sosial yang dirasakan, dan skala penerimaan diri. Individu dengan ASD akan dites oleh psikolog yang telah praktik selama 3 tahun untuk mendapatkan hasil tes kreativitas.

Saat tes dilakukan individu dengan ASD dikelompokkan setiap lima individu agar memudahkan dalam pengetesan. Namun, pada beberapa kondisi tes dilakukan secara individu. Selain itu, individu dengan ASD beberapa ada yang didampingi oleh orangtua maupun guru pendamping. Sebelum dilakukan tes, psikolog menjelaskan secara singkat mengenai tes dengan bahasa yang mudah dipahami kurang lebih selama lima menit. Waktu pengerjaan tes selama sepuluh menit. Selama tes berlangsung psikolog memotivasi individu dengan ASD untuk terus mengerjakan tes hingga waktu pengerjaan berakhir. Ketika waktu berakhir individu dengan ASD diminta untuk berhenti mengerjakan tes.

\section{Instrumen penelitian}


Tes kreativitas ini diukur dengan menggunakan Tes Kreativitas Figural yang diadaptasi dari Torrance Tests of Creative Thinking-Figural oleh Munandar (1977). Tes ini terdiri dari tiga aktivitas, yaitu membuat suatu bentuk gambar, melengkapi gambar, dan membuat bermacammacam gambar dari lingkaran sebagai sebuah rangsangan. Dimensi yang diukur pada tes ini ialah kelancaran, orisinalitas, elaborasi, dan keluwesan. Tes kreativitas figural dipilih karena memiliki reliabilitas, validitas, dan komprehensif yang lebih baik dibandingkan dengan tes kreativitas verbal (Kim, 2017). Tes yang dilakukan menggunakan satu subtes, yakni subtes lingkaran sebagai sebuah rangsangan dengan waktu pengerjaan sepuluh menit. Alasan dipilih subtes ini dikarenakan ketiga subtes mempunyai aspek pengukuran yang sama (Windaryanti, 2008). Sehingga dapat menghemat waktu.

Aspek kreativitas yang diukur dalam tes ini adalah aspek kelancaran, orisinalitas, keluwesan, dan elaborasi (Torrance, 2018). Aspek kelancaran nilai didasarkan pada kuantitas tanggapan relevan yang diberikan. Selanjutnya aspek orisinalitas, nilai ini didasarkan pada respon yang jarang dan luar biasa. Semakin banyak menggabungkan gambar, semakin besar nilai yang diberikan. Kemudian pada aspek keluwesan, nilai didasarkan pada jumlah kategori respon yang diberikan. Terakhir aspek elaborasi, nilai didasarkan pada jumlah penambahan detail pada ide minimum dasar.

Skala yang digunakan untuk mengukur dukungan sosial yang dirasakan ialah menggunakan skala Multidimensional Scale of Perceived Social Support yang diterjemahkan oleh peneliti dari Zimet, Dahlem, Zimet, \& Farley (1988), setelah itu lakukan penerjemahan kembali ke versi asli oleh seorang pengajar Bahasa Inggris di sebuah lembaga bimbingan belajar. Kemudian dilakukan penyesuaian bersama antara peneliti dengan penerjemah agar sesuai dengan versi asli. Selanjutnya keseluruhan aitem diterjemahkan kembali ke versi asli. Sehingga, skala ini siap digunakan. Skala ini untuk mengukur persepsi dukungan sosial individu. Skala yang dikembangkan oleh Zimet, Dahlem, Zimet, \& Farley (1988) ini berbentuk skala Likert dengan rentang nilai 1-7, 1 untuk sangat tidak setuju dan 7 untuk sangat setuju. Skala diuji coba kembali dan menghasilkan reliabilitas sebesar 0.918 dengan jumlah responden $\mathrm{N}=77$. Skala tersebut terdiri dari 3 subskala, yakni subskala significant other dengan aitem nomor 1, 2, 5, dan 10; subskala keluarga dengan aitem nomor $3,4,8$, dan 11 ; serta subskala teman dengan aitem nomor 6, 7, 9, dan 12 .

Skala untuk mengukur penerimaan diri pada orangtua menggunakan skala yang berbentuk skala Likert dengan rentang nilai 1-4 dengan nilai 1 sebagai jawaban sangat tidak setuju dan nilai 4 sebagai jawaban sangat setuju. Skala ini digunakan untuk mengukur penerimaan diri dan penerimaan atas orang lain dalam hal ini ialah kehadiran anak dengan ASD. Skala yang dikembangkan oleh Lestari (2017) ini diuji coba kembali dan mendapatkan reliabilitas sebesar 
0.921 dalam koefisien Alpha dengan jumlah responden $\mathrm{N}=77$. Aspek yang diukur dalam skala ini antara lain, perasaan sederajat, percaya pada kemampuan diri, bertanggung jawab, orientasi keluar diri, berpendirian, menyadari keterbatasan dan menerima kemanusiaan.

\section{Analisis}

Sebelum dilakukan uji hipotesis, penelitian ini melakukan analisis deskriptif. Kemudian penelitian ini juga melakukan uji asumsi berupa uji normalitas dan uji linearitas. Uji hipotesis dilakukan melalui analisis moderasi dengan SPSS (Hayes, 2013).

\section{Hasil}

Deskripsi data

Berdasarkan Tabel 4 dapat diketahui mengenai data deskriptif dari setiap variabel yang diteliti. Rata-rata skor variabel dukungan sosial yang rasakan adalah $69.44(S D=13.953)$. Rata-rata skor variabel penerimaan diri orangtua adalah $259.44(S D=23.923)$. Rata-rata skor variabel kreativitas figural anak adalah $87.15(S D=13.634)$.

\section{Tabel 4.}

Deskripsi Data

\begin{tabular}{|c|c|c|c|c|c|}
\hline & $\mathrm{N}$ & Minimum & Maksimum & Mean & SD \\
\hline Penerimaan Diri & 34 & 212 & 302 & 259.44 & 23.924 \\
\hline $\begin{array}{l}\text { Dukungan Sosial } \\
\text { yang Dirasakan }\end{array}$ & 34 & 12 & 84 & 69.44 & 13.953 \\
\hline T. Kreativitas & 34 & 67 & 120 & 87.15 & 13.634 \\
\hline
\end{tabular}

Uji asumsi

Terdapat dua uji asumsi yang harus dipenuhi sebelum dilakukan uji hipotesis. Uji asumsi tersebut adalah uji normalitas dan uji linearitas. Dapat dilihat dari Tabel 5 yang menunjukkan bahwa data setiap variabel penelitian berdistribusi normal. Hal ini ditunjukkan oleh nilai $p$ yang lebih besar dari 0.05 . Kemudian setelah melakukan uji normalitas, peneliti melakukan uji linearitas. Hasil uji linearitas didapatkan hasil nilai signifikansi deviasi linearitas pada variabel dukungan sosial yang dirasakan terhadap variabel kreativitas adalah 0.754 dan lebih besar dari 0.05. Sehingga dapat disimpulkan bahwa terdapat hubungan linear antara variabel dukungan 
sosial dengan variabel kreativitas. Nilai signifikansi deviasi linearitas pada variabel penerimaan diri orangtua terhadap kreativitas menunjukkan angka 0.277 dan lebih besar dari 0.05 . Sehingga dapat disimpulkan bahwa terdapat hubungan linear antara variabel penerimaan diri orangtua dengan variabel kreativitas. Nilai signifikansi deviasi linearitas pada variabel dukungan sosial yang dirasakan terhadap variabel penerimaan diri orangtua menunjukkan angka 0.459 dan lebih besar dari 0.05. Sehingga dapat disimpulkan bahwa terdapat hubungan linear antara variabel dukungan sosial yang dirasakan terhadap variabel penerimaan diri pada orangtua. Berdasarkan Tabel 6 maka dapat dilakukan uji hipotesis karena setiap variabel memiliki hubungan linear.

Tabel 5.

Hasil Uji Normalitas

\begin{tabular}{lcc}
\hline Variabel & K-S Z & $\mathrm{p}$ \\
\hline Penerimaan Diri Orangtua (X) & 0.522 & $\mathrm{P}>0.05$ \\
Dukungan Sosial yang Dirasakan (W) & 0.976 & $\mathrm{P}>0.05$ \\
T. Kreativitas (Y) & 1.024 & $\mathrm{P}>0.05$ \\
\hline
\end{tabular}

Tabel 6.

Hasil Uji Linearitas

\begin{tabular}{lllllll}
\hline Variabel & \multicolumn{1}{c}{ Deviasi Linearitas } & $\mathrm{p}$ \\
\hline $\begin{array}{l}\text { Penerimaan Diri } \\
\text { Kreativitas (Y) }\end{array}$ & & & & \\
\hline
\end{tabular}


Dukungan Sosial yang Dirasakan (W) $* 0.754 \quad \mathrm{P}>0.05$

Kreativitas (Y)

Dukungan Sosial yang Dirasakan $(\mathrm{W}) * 0.459 \quad \mathrm{P}>0.05$

Penerimaan Diri Orangtua (X)

\section{Uji hipotesis}

Sebelum dilakukan uji hipotesis, hasil dukungan sosial yang dirasakan oleh orangtua yang berbentuk skala diubah menjadi dua bentuk kategori, yakni rendah untuk skor di bawah ratarata dan tinggi untuk skor di atas rata-rata. Berdasarkan uji moderasi melalui metode regresi berjenjang yang telah dilakukan (tabel 7), didapatkan hasil bahwa penerimaan diri pada orangtua $(\mathrm{X})$ terhadap kreativitas menunjukkan sumbangan prediktor $8.2 \%$ dan nilai signifikansi F sebesar 0.101. Hal ini menunjukkan bahwa penerimaan diri pada orangtua tidak memprediksi kreativitas individu dengan ASD secara signifikan. Sehingga, hipotesis 1 ditolak. Selanjutnya, ketika dukungan sosial yang dirasakan oleh orangtua ditambahkan, dukungan sosial yang dirasakan oleh orangtua menunjukkan sumbangan prediktor $19.4 \%$ dan nilai signifikansi F sebesar 0.047. Artinya dukungan sosial yang dirasakan oleh orangtua mampu memprediksi kreativitas individu dengan ASD secara signifikan. Sehingga, hipotesis 2 diterima. Kemudian ketika hasil perkalian penerimaan diri pada orangtua dan dukungan sosial yang dirasakan oleh orangtua ditambahkan, hasil perkalian penerimaan diri pada orangtua dan dukungan sosial yang dirasakan oleh orangtua menunjukkan sumbangan prediktor $23.2 \%$ dan nilai signifikansi F sebesar 0.230 . Hal tersebut berarti hasil kali dukungan sosial yang dirasakan oleh orangtua dan penerimaan diri pada orangtua tidak memprediksi kreativitas individu dengan ASD secara signifikan. Sehingga, dukungan sosial yang dirasakan oleh orangtua tidak memoderasi hubungan antara penerimaan diri pada orangtua terhadap kreativitas individu dengan ASD. Hal ini dapat diartikan bahwa variabel dukungan sosial bukan variabel moderator. Artinya, hipotesis 3 ditolak. Dapat dilihat pada tabel 8 Model 3, diketahui persamaan regresi yang memuat semua variabel prediktor ialah $\mathrm{Y}=157.815-0.256 \mathrm{X}-67.179 \mathrm{~W}+0.224 \mathrm{XW}$.

\section{Tabel 7.}

Rangkuman Perubahan Model Regresi dalam Berjenjang

\begin{tabular}{lllllll}
\hline Model & $\mathrm{R}$ & $\mathrm{R}$ & $\mathrm{R}$ Kuadrat \\
& & Kuadrat & Disesuaikan & $\begin{array}{l}\text { Perubahan } \\
\text { Kuadrat }\end{array}$ & $\begin{array}{l}\text { Perubahan } \\
\text { Sig. F }\end{array}$ \\
\hline 1 & $0.286^{\mathrm{a}}$ & 0.082 & 0.053 & 0.082 & 0.101
\end{tabular}


WACANA

$\begin{array}{llllll}2 & 0.440^{\mathrm{b}} & 0.194 & 0.141 & 0.112 & 0.047 \\ 3 & 0.482^{\mathrm{c}} & 0.232 & 0.155 & 0.038 & 0.230\end{array}$

Keterangan: signifikan apabila $p<0.05$

Tabel 8.

Nilai Koefisien Regresi

\begin{tabular}{|c|c|c|c|c|}
\hline Mo & & B & $\mathrm{t}$ & Sig. \\
\hline 1 & (Konstanta) & 129.441 & 5.147 & .000 \\
\hline & Penerimaan Diri Orangtua (X) & -.163 & -1.689 & .101 \\
\hline 2 & (Konstanta) & 129.801 & 5.420 & .000 \\
\hline & Penerimaan Diri Orangtua & -.147 & -1.594 & .121 \\
\hline & Dukungan Sosial yang Dirasak & $n-9.009$ & -2.072 & .047 \\
\hline & $(W)$ & & & \\
\hline 3 & (Konstanta) & 157.815 & 4.785 & .000 \\
\hline
\end{tabular}


WACANA

$\begin{array}{llll}\text { Penerimaan Diri Orangtua (X) } & -.256 & -2.006 & .054 \\ \text { Dukungan Sosial yang Dirasakan-67.179 } & -1.408 & .169 \\ \text { (W) } & & \\ \text { Penerimaan Diri Orangtua (X) *.224 } & 1.224 & .230 \\ \text { Dukungan Sosial yang Dirasakan } & & \\ (W) & \end{array}$

a. Prediktor: (Konstanta), Penerimaan Diri, Dukungan Sosial, Penerimaan Diri * Dukungan Sosial

\section{Gambar 1.}

Grafik Analisis Regresi dengan Moderator 


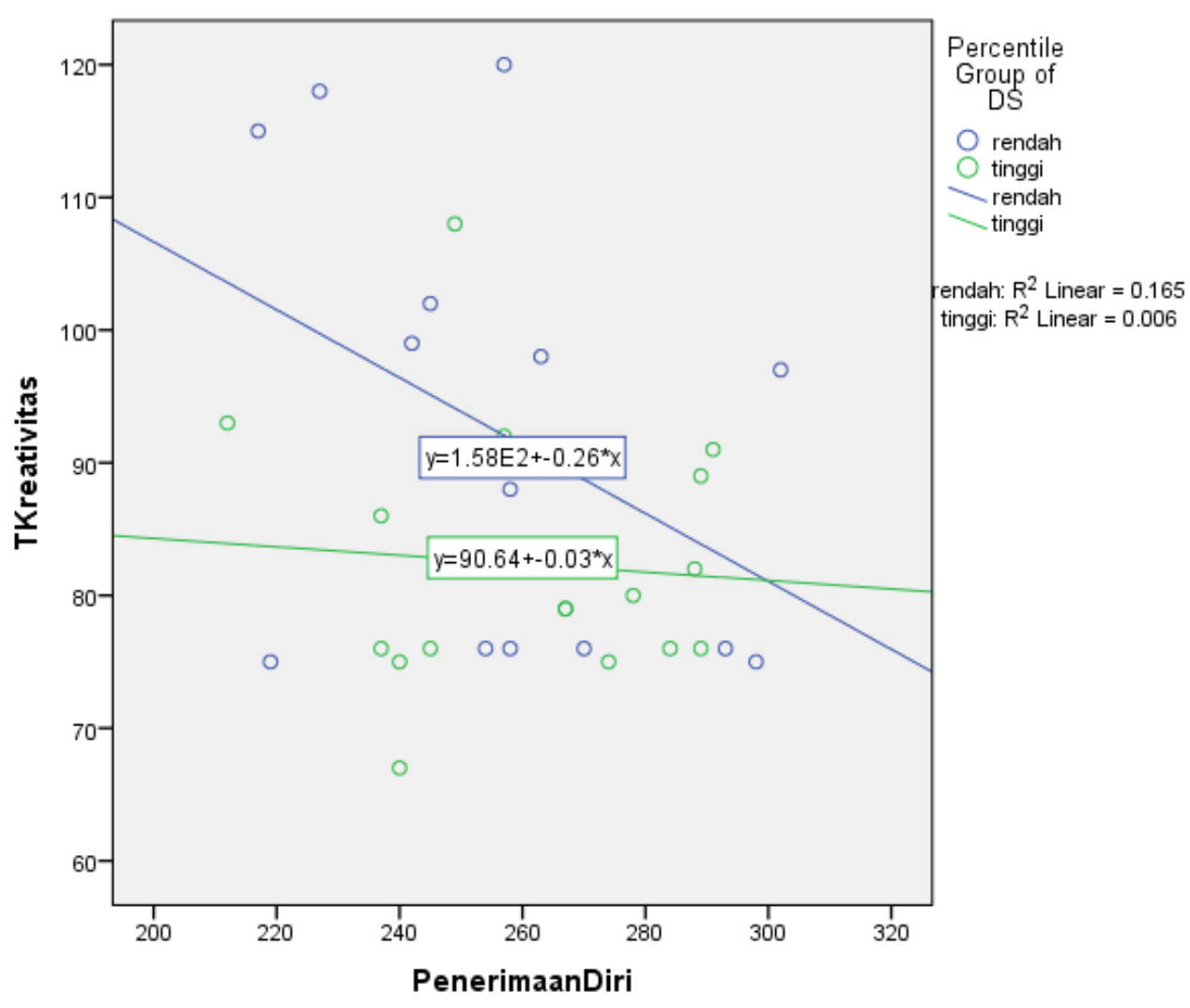

Berdasarkan dari gambar 1 dapat dilihat bahwa terdapat dua garis. Garis yang berwarna violet, pada dukungan sosial yang dirasakan oleh orangtua rendah menunjukkan bahwa semakin tinggi penerimaan diri pada orangtua tidak diikuti dengan meningkatnya kreativitas individu dengan ASD, justru kreativitas individu dengan ASD menurun. Begitu pula dengan garis warna hijau, jika dukungan sosial yang dirasakan oleh orangtua tinggi, maka hal ini menunjukkan bahwa semakin tinggi penerimaan diri pada orangtua tidak diikuti dengan meningkatnya kreativitas individu dengan ASD. Sebaliknya kreativitas individu dengan ASD menurun. Akan tetapi penurunannya tidak signifikan.

\section{Diskusi}

Berdasarkan hasil pengujian regresi berjenjang didapatkan bahwa dukungan sosial yang dirasakan oleh orangtua dapat memprediksi kreativitas individu dengan ASD secara signifikan. Hasil tersebut sejalan dengan penelitian Green, Furrer, \& McAllister (2007) bahwa orangtua dengan lebih banyak dukungan sosial menunjukkan peningkatan kegiatan orangtua dan anak dari waktu ke waktu dan dapat digunakan sebagai sarana bimbingan untuk meningkatkan kreativitas. Hal ini sesuai dengan pola asuh otoritatif yang sesuai individu dengan ASD. Pola asuh otoritatif ini berdampak terhadap kreativitas individu dengan ASD karena adanya rangsangan melalui latihan yang diberikan (De Caroli, Falanga, Licciardello, \& Sagone, 2017; Astuti, 2017). 
Penelitian ini juga menunjukkan bahwa penerimaan diri pada orangtua tidak dapat memprediksi kreativitas individu dengan ASD secara signifikan. Berbeda dengan penelitian Oana, DiGiuseppe, \& David (2013) yang menyatakan bahwa dengan pola asuh yang sesuai, penerimaan diri pada orangtua dapat berpengaruh terhadap kreativitas. Begitu pula dengan dukungan sosial yang dirasakan oleh orangtua tidak berperan sebagai moderator dalam hubungan penerimaan diri pada orangtua terhadap kreativitas individu dengan ASD. Perbedaan penelitian ini dengan penelitian sebelumnya kemungkinan disebabkan oleh penerimaan diri pada orangtua yang berbeda-beda. Orangtua dengan penerimaan diri dapat menerapkan pola pengasuhan otoritatif yang sesuai untuk individu dengan ASD (Oana, DiGiuseppe, \& David, 2013). Pola asuh otoritatif ini akan berpengaruh pada kreativitas (Astuti, 2017). Pada penelitian sebelumnya dijelaskan bahwa orangtua dari individu dengan ASD yang menerima dukungan sosial dapat meningkat penerimaan diri dari orangtua tersebut (Lestari, 2017; Kumalasari, 2019).

Faktor lain yang memengaruhi kreativitas pada individu dengan ASD ialah faktor genetik yang berpengaruh pada berpikir divergen dan konvergen (Han, dkk., 2018). Gen yang berpengaruh pada berpikir divergen ialah Single Nucleotide Polymorphisms (SNP) di DRD2 (Reuter dkk., 2006), sedangkan gen yang berpengaruh pada berpikir konvergen ialah polymorphisms dua SNP di DRD2 (rs1800467 \& rs6278) (Zhang \& Zhang, 2016) dan sebuah SNP dalam COMT (rs5993883) (Jiang, Shang \& Su, 2015). Menurut Guilford (1967) proses berpikir divergen dan konvergen diyakini memberikan peran yang saling melengkapi untuk membentuk perilaku kreatif. Berpikir divergen ialah cara berpikir dengan mengeluarkan ide sebanyak mungkin untuk menghasilkan ide kreatif, sedangkan berpikir konvergen ialah cara berpikir secara berurutan dengan berfokus pada mencari jawaban yang benar untuk menyelesaikan masalah (Sumarta \& Handranata, 2017). Hal ini didukung pula oleh data tambahan dari hasil wawancara orangtua dari individu dengan ASD yang kebetulan mendapakan skor kreativitas tertinggi menyatakan bahwa baik dari ayah maupun ibu memiliki bakat kreativitas terutama pada seni musik. Kedua orangtua anak tersebut merupakan anggota band sewaktu SMA.

Selain dikarenakan faktor gen, kreativitas pada individu dengan ASD dapat dipengaruhi oleh bentuk rangsangan melalui latihan yang diberikan oleh orang-orang disekitar, khususnya orangtua. Hasil wawancara pada dua orangtua individu dengan ASD menunjukkan bahwa orangtua memberikan latihan dengan cara yang berbeda. Salah satu orangtua memberikan latihan dengan mencontohkan hal-hal yang sederhana dan faktual. Selain itu, komunikasi yang digunakan bersifat satu arah. Pada orangtua yang lain, orangtua memberikan latihan dengan berbagai alat, seperti alat lukis maupun gambar dan komputer. Ditambah orangtua tersebut juga menanyakan hal-hal yang dikerjakan oleh individu dengan ASD tersebut. Sehingga individu 
tersebut terbiasa untuk bercerita. Terbukti bahwa bercerita sebagai bentuk latihan dapat berkontribusi positif terhadap perkembangan kreativitas terutama pada aspek keluwesan, keaslian, dan elaborasi (Catala, Theune, Gijlers, \& Heylen, 2017; De Caroli, Falanga, Licciardello, \& Sagone, 2017).

Faktor lain yang kemungkinan juga menyebabkan hasil penelitian ini berbeda dengan penelitian sebelumnya ialah juga dipengaruhi oleh faktor internal setiap individu. Faktor internal terbukti memiliki hubungan dengan kreativitas (Da Costa, Páez, Sánchez, Garaigordobil, \& Gondim, 2015). Faktor internal tersebut, seperti creative self-efficacy. Menurut (Farmer, Tierney, \& KungMcIntyre, 2003) creative self-efficacy didefinisikan sebagai kepercayaan diri individu atas kemampuannya untuk menjadi kreatif. Hasil penelitian menunjukkan bahwa creative selfefficacy berhubungan positif terhadap performansi kreatif (Tierney \& Farmer, 2011). Faktor internal lain yang juga penting dalam kreativitas ialah motivasi intrinsik (Amabile, 1996). Hal ini karena motivasi intrinsik dianggap mempromosikan kreativitas melalui perasaan menghargai kompetensi dan minat yang berkontribusi pada pengembangan berkelanjutan dari pengetahuan dan keterampilan yang relevan dengan kreativitas (Steele, Mcintosh, \& Higgs, 2017).

Faktor luar lain yang kemungkinan memengaruhi hasil penelitian mengenai hubungan antara variabel prediktor, moderator, dan kriteria pada penelitian ini ialah faktor tingkat keparahan ASD pada individu. Menurut DSM-V yang diterbitkan oleh APA (2013), anak ASD yang memiliki tingkat keparahan autis yang berat memiliki respon yang rendah terhadap ajakan interaksi sosial dari orang lain. Sehingga anak tersebut memiliki respon yang terbatas ketika menjalani interaksi sosial dan kesulitan memahami instruksi yang diberikan orang lain. Selain itu, jumlah sampel yang digunakan kurang mewakili populasi, mengingat sampel yang digunakan dalam penelitian ini hanya sebanyak 34 individu dengan ASD dan orangtua. Pengaruh jumlah sampel dijelaskan oleh penelitian Fairchild \& MacKinnon (2009) bahwa signifikansi statistik dari suatu pengujian didasarkan pada empat parameter, yaitu ukuran sampel, ukuran efek, kekuatan, dan set level alfa untuk percobaan.

Penelitian ini memiliki beberapa keterbatasan. Pertama mengenai terbatasnya waktu dan biaya maka penelitian hanya dapat dilakukan di lima tempat. Sehingga jumlah responden yang didapatkan sedikit dan hanya dapat mewakili individu dengan karakteristik yang mirip dengan partisipan penelitian ini. Kedua kesulitan mendapat izin dari pihak instansi yang akan menjadi tempat pengambilan data serta kesulitan mendapat responden orangtua yang bersedia mengikuti penelitian ini. Ketiga, tidak ada penyeragaman tingkat keparahan individu dengan ASD yang menjadi responden penelitian. Terakhir, tidak adanya kontrol pada faktor-faktor lain pada responden seperti faktor latar belakang. 


\section{Kesimpulan}

Berdasarkan hasil pembahasan penelitian di atas, dapat disimpulkan bahwa dukungan sosial yang dirasakan oleh orangtua dapat memprediksi kreativitas individu dengan ASD. Selain itu, penerimaan diri pada orangtua tidak dapat memprediksi kreativitas individu dengan ASD. Begitu pula dukungan sosial yang dirasakan orangtua tidak berperan sebagai moderator dalam hubungan penerimaan diri pada orangtua terhadap kreativitas individu dengan ASD. Oleh sebab itu, hipotesis dinyatakan 1 dan 3 ditolak, sedangkan hipotesis 2 diterima.

Saran

Saran untuk penelitian selanjutnya adalah dengan menambah jumlah sampel supaya hasil dapat digeneralisasi. Kemudian, dengan menambah informasi mengenai data demografi. Sehingga dapat diketahui faktor-faktor lain yang dapat berpengaruh. Selain itu, perlu adanya penelitian lebih lanjut dengan variabel dependen dapat diganti oleh penyandang disabilitas lainnya. Hal ini agar dapat dijadikan pedoman perencanaan program bagi pemerintah maupun pihak instansi terutama sekolah luar biasa.

\section{Kepustakaan}

Adip, N. N., Ibrahim, M. I., Rahman, A. A., Bakar, R. S., Yahaya, N. A., Hussin, S., \& Mansor, W. (2019). Perceived Stress among Caregivers of Children with Autism Spectrum Disorder: A StateWide Study. Int J Environ Res Public Health, 16(8). doi:10.3390/ijerph16081468

Al-Dujaili, A. H., \& Al-Mosssawy, D. A. (2017). Psychosocial Burden among Caregivers of Children with Autism Spectrum Disorder in Najaf Province. Curr Pediatr Res, 21(2), 272-282.

Alsa, A. (2007). Pendekatan Kuantitatif dan Kualitatif serta Kombinasinya dalam Penelitian Psikologi (ed. 3). Yogyakarta: Pustaka Pelajar Offset.

American Psychiatric Association. (2013). Diagnostic And Statistical Manual of Mental Disorder Edition "DSM-5". Washinton DC: American Psychiatric Publishing.

Assadi, M., Zokayi, N., Kaviani, H., Mohammadi, M., \& Gohari, M. (2006). Relationship between Children Socio-Cultural Background, Parenting Style, Academic Achievement and Learning Styles. Journal of Psychiatry and Clinical Psychology of Iran, 21-35.

Astorga, M. L. (2014). The Concept of Creativity in Art and in Science: Are Autistic People Creative?. Khazar Journal of Humanities and Social Sciences, 17, 49-67. doi:10.5782/22232621.2014.17.3.49

Astuti, P. (2017). Pengaruh Pola Asuh Orangtua terhadap Kreativitas Anak di Tk Negeri Kecamatan Muara Bulian Kabupaten Batanghari. (Naskah tidak dipublikasikan). Fakultas Keguruan dan Ilmu Pendidikan. Universitas Jambi, Jambi.

Baumrind, D. (1991). The Influence of Parenting Style on Adolescent Competence and Substance Use. Journal of Early Adolescence, 11, 56-95. doi:10.1177/0272431691111004

Best, C., Arora, S., Porter, F., \& Doherty, M. (2015). The Relationship Between Subthreshold Autistic Traits, Ambiguous Figure Perception and Divergent Thinking. Journal of Autism and Developmental, 45(12), 4064-4073. doi:10.1007/s10803-015-2518-2 
Carson, S. H., \& Langer, E. J. (2006). Mindfulness and Self Acceptance. Journal of RationalEmotive \& Cognitive-Behavior Therapy, 24(1), 29-43. doi:10.1007/s10942-006-0022-5

Casanova, M. F., Switala, A. E., Trippe, J., \& Fitzgerald, M. (2007). Comparative Minicolumnar Morphometry of Three Distinguished Scientists. Autism, 11(6), 557-569. doi:10.1177/1362361307083261

Casanova, M., \& Trippe, J. (2009). Radial Cytoarchitecture and Patterns of Cortical Connectivity in Autism. Philosophical Transactions of the Royal Society B: Biological Sciences, 364(1522), 1433-1436. doi:10.1098/rstb.2008.0331

Catala, A., Theune, M., Gijlers, H., \& Heylen, D. (2017). Storytelling as a Creative Activity in the Classroom. C and C 2017 - Proceedings of the 2017 ACM SIGCHI Conference on Creativity and Cognition, 237-242.

Cloete, L. G., \& Obaigwa, E. O. (2019). Lived Experiences of Caregivers of Children with Autism Spectrum Disorder in Kenya. African Journal of Disability, 8. doi:10.4102/ajod.v8i0.435

Colbert, D., Drogomyretska, K., \& Fox, R. (2020). Stress and Perceived Social Support in Parents of Children with ASD. Journal of Autism and Developmental Disorders. doi:10.1007/s10803-02004455-x

Craig, J., \& Cohen, B. (1999). Creativity and Imagination in Autism and Asperger Syndrome. Journal of Autism and Developmental Disorder, 29(4), 319-326. doi:10.1023/A:1022163403479

Davis, P. E., Simon, H., Meins, E., \& Robins, D. L. (2018). Imaginary Companions in Children with Autism Spectrum Disorder. Journal of Autism and Developmental Disorders, 48, 2790-2799.

Da Costa, S., Páez, D., Sánchez, F., Garaigordobil, M., \& Gondim, S. (2015). Personal Factors of Creativity: A Second Order Meta-analysis. Organizaciones, 31(3), 165-173. doi:10.1016/j.rpto.2015.06.002

De Caroli, M. E., Falanga, R., Licciardello, O., \& Sagone, E. (2017). How can We Enhance Creativity in Childhood? An Action Research with Italian Children. International Journal of Developmental and Educational Psychology, 1(1), 95-102. doi:10.17060/ijodaep.2017.n1.v1.902

Eagle, D. E., Hybels, C. F., \& Proeschold-Bell, R. J. (2018). Perceived Social Support, Received Sosial Support, and Depression Among Clergy. Journal of Social and Personal Relationships, 1-19. doi:10.1177/0265407518776134

Eaves, L. C., \& Ho, H. H. (2007). Young Adult Outcome of Autism Spectrum Disorders. Journal of Autism and Developmental Disorders, 38(4), 739-747. doi:10.1007/s10803-007-0441-x

Fairchild, A. J., \& MacKinnon, D. P. (2009). A General Model for Testing Mediation and Moderation Effects. Prevention science : the official journal of the Society for Prevention Research, 10(2), 87-99. doi:10.1007/s11121-008-0109-6

Farmer, S. M., Tierney, P., \& Kung-McIntyre, K. (2003). Employee creativity in Taiwan: An Application of Role Identity Theory. The Academy of Management Journal, 46(5), 618-630. doi: $10.2307 / 30040653$

Fulton, E., Eapen, V., Crncec, R., Walter, A., \& Rogers, S. (2014). Reducing Maladaptive Behaviors in Preschool-aged Children with Autism Spectrum Disorder Using the Early Start Denver Model. Original Research Article, 2. doi:10.3389/fped.2014.00040

Green, B. L., Furrer, C., \& McAllister, C. (2007). How Do Relationships Support Parenting? Effects of Attachment Style and Social Support on Parenting Behavior in an At-Risk Population. American Journal of Community Psychology, 40, 96-108. doi:10.1007/s10464-007-9127-y

Guilford, J. P. (1950). Creativity. The American Psychologist, 444-454. 
Guilford, J. P. (1967). Creativity: Yesterday, Today, and Tomorrow. The Journal of Creative Behavior, 1(1), 3-14. doi:10.1002/j.2162-6057.1967.tb00002.x

Guilford, J.P. (1967). The Nature of Human Intelligence. New York: McGraw-Hill.

Han, W., Zhang, M., Feng, X., Gong, G., Peng, K., \& Zhang, D. (2018). Genetic Influences on Creativity: An Exploration of Convergent and Divergent Thinking. PeerJ. doi:10.7717/peerj.5403

Happe, F., \& Vital, P. (2009). What Aspects of Autism Predispose to Talent? Philosophical Transactions of the Royal Society B: Biological Sciences, 364(1522), 1369-1375. doi:10.1098/rstb.2008.0332

Hayes, F. A. (2013). Introduction to Mediation, Moderation, and Conditional Process Analysis : A Regressionbased Approach. New York: The Guilford Press.

Hillier, A., Campbell, H., Mastriani, K., Izzo, M. V., Kool-Tucker, A. K., Cherry, L., \& Beversdorf, D. Q. (2007). Two-Year Evaluation of a Vocational Support Program for Adults on the Autism Spectrum. Career Development for Exceptional Individuals, 30(1), 35-47. doi:10.1177/08857288070300010501

Hoefman, R., Payakachat, N., Exel, J. v., Kuhlthau, K., Kovacs, E., Pyne, J., \& Tilford, J. M. (2014). Caring for a Child with Autism Spectrum Disorder and Parents' Quality of Life: Application of the CarerQol. J Autism Dev Disord, 44(8), 1933-1945. doi:10.1007/s10803-014-2066-1

Honeck, E. (2016). Inspiring Creativity in Teachers to Impact Students. Torrance Journal for Applied Creativity, 33-38.

Ibrahimi, S., Durmishi, L., \& Ibrahimi, E. (2019). Relation between Autism Spectrum Disorder and Parenting Styles. Open Journal for Psychological Research, 3(2), 47-54.

doi:10.32591/coas.ojpr.0302.02047i

Ilias, K., Cornish, K., Kummar, A. S., Sang-Ah Park, M., \& Golden, K. J. (2018). Parenting Stress and Resilience in Parents of Children With Autism Spectrum Disorder (ASD) in Southeast Asia: A Systematic Review. Front Psychol, 9. doi:10.3389/fpsyg.2018.00280

Jiang W, Shang S, Su Y. 2015. Genetic Influences on Insight Problem Solving: the Role of Catechol-0Methyltransferase (COMT) Gene Polymorphisms. Frontiers in Psychology 6(13):1569. doi:10.3389/fpsyg.2015.01569

Kasirer, A., \& Mashal, N. (2014). Verbal Creativity in Autism: Comprehension and Generation of Metaphoric Language in High-Functioning Autism Spectrum Disorder and Typical Development. Frontiers in Human Neuroscience, 8(16). doi:10.3389/fnhum.2014.00615

Kementerian Pemberdayaan Perempuuan dan Perlindungan Anak Republik Indonesia. (2018, 18 April). Hari Peduli ASD Sedunia: Kenali Gejalanya, Pahami Keadaannya. Diunduh dari https://www.kemenpppa.go.id/index.php/page/read/31/1682/hari-peduli-ASD-sedunia-kenaligejalanya-pahami-keadaannya tanggal 12 April 2019.

Kim, K. H. (2017). The Torrance Tests of Creative Thinking - Figural or Verbal: Which One Should We Use? Creativity. Theories - Research - Applications, 4(2), 303-321. doi:10.1515/ctra-2017-0015

Kinnear, S. H., Link, B. G., Ballan, M. S., \& Fischbach, R. L. (2016). Understanding the Experience of Stigma for Parents of Children with Autism Spectrum Disorder and the Role Stigma Plays in Families' Lives. $J$ Autism Dev Disord, 46, 942-953. doi:10.1007/s10803-015-2637-9

Kumalasari, A. R. (2019). Hubungan antara Dukungan Sosial dengan Penerimaan Diri pada Orangtua dengan Anak Berkebutuhan Khusus. (Naskah tidak dipublikasikan). Fakultas Psikologi. Universitas Katolik Soegijapranata, Semarang.

Lestari, R. A. (2017). Hubungan Antara Dukungan Sosial Dengan Penerimaan Diri Orangtua Yang Memiliki Anak Autis Di Yakita School Medan. (Naskah tidak dipublikasikan). Fakultas Psikologi. Universitas Medan Area, Medan. 
Lu, M. H., Wang, G. H., Lei, H., Shi, M. L., Zhu, R., \& Jiang, F. (2018). Social Support as Mediator and Moderator of the Relationship Between Parenting Stress and Life Satisfaction Among the Chinese Parents of Children with ASD. Journal of Autism and Developmental Disorders, 48(4), 1181-1188. doi:10.1007/s10803-017-3448-y

Lucas, B., G. Claxton and E. Spencer (2013), "Progression in Student Creativity in School: First Steps Towards New Forms of Formative Assessments”, OECD Education Working Papers, No. 86, OECD Publishing. doi:10.1787/5k4dp59msdwk-en

Mak, W. W., \& Kwok, Y. T. (2010). Internalization of Stigma for Parents of Children with Autism Spectrum Disorder in Hong Kong. Social Science \& Medicine, 70(12), 2045-2051. doi:10.1016/j.socscimed.2010.02.023

Mansell, W., \& Morris, K. (2004). A Survey of Parents' reactions to the Diagnosis of An Autistic Spectrum Disorder by A Local Service. Autism, 8(4), 387-07. doi: 10.1177/1362361304045213

Novianggraini, E. (2012). Hubungan Kreativitas Anak Dengan Pola Asuh Orangtua Di Tk Desa Leteh Kabupaten Rembang Tahun Ajaran 2011/2012. (Naskah tidak dipublikasikan). Fakultas Fakultas Keguruan dan Ilmu Pendidikan. Universitas Muhammadiyah Surakarta, Surakarta.

Oana, G. A., DiGiuseppe, R., \& David, D. (2013). Self-Acceptance and the Parenting of Children. The Strength of Self-Acceptance, 193-214. doi:10.1007/978-1-4614-6806-6_11

Onaolapo, O. J., \& Onaolapo, A. Y. (2017). Global Data on Autism Spectrum Disorders Prevalence: A Review of Facts, Fallacies and Limitations. Universal Journal of Clinical Medicine, 5(2), 14-23. doi:10.13189/ujcm.2017.050202

Opris, I., \& Casanova, M. F. (2014). Prefrontal Cortical Minicolumn: from Executive Control to Disrupted Cognitive Processing. Brain, 137(7), 1863-1875. doi:10.1093/brain/awt359

Orpana, H., \& O’Shea, M. (2012). The Role of Social Support in Reducing Psychological Distress. Ottawa: Canadian Institute for Health Information.

Ozgur, B. G., Aksu, H., \& Eser, E. (2018). Factors Affecting Quality of Life of Caregivers of Children Diagnosed with Autism Spectrum Disorder. Indian J Psychiatry, 60(3), 278-285.

doi:10.4103/psychiatry.IndianJPsychiatry_300_17

Picardi, A., Gigantesco, A., Tarolla, E., Stoppioni, V., Cerbo, R., Cremonte, M., ... Nardocci, F. (2018).

Parental Burden and its Correlates in Families of Children with Autism Spectrum Disorder: A Multicentre Study with Two Comparison Groups. Clinical Practice \& Epidemiology in Mental Health, 31(14), 143-176. doi:10.2174/1745017901814010143

Ramanda, A. N. (2008). Dinamika Penerimaan Ibu terhadap Anak Tuna Grahita. (Naskah tidak dipublikasikan). Fakultas Psikologi. Universitas Islam Negeri Syarif Hidayatullah, Jakarta.

Reblin, M., \& Uchino, B. N. (2008). Social and Emotional Support and Its Implication for Health. Current Opinion in Psychiatry, 21(2), 201-205. doi:10.1097/YC0.0b013e3282f3ad89

Reuter M, Roth S, Holve K, Hennig J. (2006). Identification of First Candidate Genes for Creativity: A Pilot Study. Brain Research 1069(1):190-197. doi:10.1016/j.brainres.2005.11.046

Roohafza, H. R., Afshar, H., Keshteli, A. H., Mohammadi, N., Feizi, A., Taslimi, M., \& Peymann, A. (2014). What's the Role of Perceived Social Support and Coping Styles in Depression. J Res Med Sci, 19(10), 944949.

Service, D. O. (2007). Autism Spectrum Disorders Pervasive Developmental Disorders. National Institute Of Mental Health.

Steele, L., Mcintosh, T., \& Higgs, C. (2017). Intrinsic Motivation and Creativity: Opening Up A Black Box. In M. D. Mumford, \& S. Hemlin, Handbook of Research on Creativity and Leadership, 100-130. 
Sumarta, F., \& Handranata, Y. W. (2017, July 18). Divergent And Convergent Thinking. Diunduh dari Https://Bbs.Binus.Ac.Id/Business-Creation/2017/07/Divergent-And-Convergent-Thinking tanggal 13 Mei 2020.

Taylor, Z. E., Conger, R. D., Robins, R. W., \& Widaman, K. F. (2015). Parenting Practices and Perceived Social Support: Longitudinal Relations with the Social Competence of Mexican-origin Children. J Lat Psychol, 3(4), 193-208. doi:10.1037/lat0000038

Tierney, P., \& Farmer, S. M. (2011). Creative Self-efficacy Development and Creative Performance Over Time. Journal of Applied Psychology, 96(2), 277-293. doi:10.1037/a0020952

Torrance, E. P. (2018). Torrance Test of Creative Thinking. Bensenville: Published by Scholastic Testing Service, Inc.

Tung, L., Huang, C., Tseng, M., Yen, H., Tsai, Y., \& Lin, Y. (2014). Correlates of Health- related Quality of Life and the Perception of Its Importance in Caregivers of Children with Autism. Research in Autism Spectrum Disorders, 8(9), 1235-1242. doi:10.1016/j.rasd.2014.06.010

Walen, H. R., \& Lachman, M. E. (2000). Social Support and Strain from Partner, Family, and Friends: Costs and Benefits for Men and Women In Adulthood. Journal of Social Personal Relasionships, 17(1), 5-30. doi:10.1177/0265407500171001

Wang, L., Mandell, D. S., Lawer, L., Cidav, Z., \& Leslie, D. L. (2013). Healthcare Service Use and Costs for Autism Spectrum Disorder: A Comparison Between Medicaid and Private Insurance. J Autism Dev Disord, 43(5), 1057-1064. doi:10.1007/s10803-012-1649-y

Weiss, J. A., Cappadocia, M. C., MacMullin, J. A., Viecili, M., \& Lunsky, Y. (2012). The Impact of Child Problem Behaviors of Children with ASD on Parent Mental Health: The Mediating Role of Acceptance And Empowerment. Autism, 16(3), 261-274. doi: 10.1177/1362361311422708

Wilson, C., Lennox, P.P., Hughes, G.\& Brown, M. (2017) How to Develop Creative Capacity for the Fourth Industrial Revolution: Creativity and Employability in Higher Education in Reisman, F. Ed., Creativity, Innovation and Wellbeing. London: KIE Conference Publications.

Windaryanti, A. (2008). Hubungan antara Kreativitas dengan Frekuensi Bermain Game Elektronik pada Anak-Anak SD Kanisius Baciro Yogyakarta. (Naskah tidak dipublikasikan). Fakultas Psikologi. Universitas Sanata Dharma, Yogyakarta.

World Health Organization. (2019, 7 November). Autism Spectrum Disorder. Diunduh dari https://www.who.int/news-room/fact-sheets/detail/autism-spectrum-disorders tanggal 12 Desember 2019.

Yuananti, P. (2017). Pengaruh Dukungan Sosial Terhadap Depresi dan Kecemasan Caregiver Skizofrenia di RSJD Surakarta. (Naskah tidak dipublikasikan). Fakultas Kedokteran. Universitas Sebelas Maret, Surakarta.

Zhang S, Zhang J. 2016. The Association of DRD2 with Insight Problem. Solving. Frontiers in Psychology, 7. doi:10.3389/fpsyg.2016.01865

Zimet, G., Dahlem, N., Zimet, S., \& Farley, G. (1988). The Multidimensional Scale of Perceived Social Support. Journal of Personality Assessment, 52, 30-41. 